\title{
PEMERIKSAAN BASIL TAHAN ASAM (BTA) PADA SPUTUM PENDERITA BATUK $\geq 2$ MINGGU DI POLIKLINIK PENYAKIT DALAM BLU RSUP. PROF. Dr. R.D KANDOU MANADO
}

\author{
${ }^{1}$ Diana Susanti \\ ${ }^{2}$ Constantien Kountul \\ ${ }^{2}$ Velma Buntuan
}

\author{
${ }^{1}$ Kandidat Skripsi Fakultas Kedokteran Unsiversitas Sam Ratulangi Manado \\ ${ }^{2}$ Bagian Mikrobiologi Fakultas Kedokteran Universitas Sam Ratulangi Manado \\ Email: Diana.susanti09207@yahoo.com
}

\begin{abstract}
Abstrack: Cough $\geq 2$ weeks are the main symptoms of tuberculosis diagnosis accompanied by phlegm.Symptoms that accompany the cough bleed, decreased appetite,weight loss, night sweats (no activity) and no signs of infection. Tuberculosis is a disease of the lungs caused by gram-positive rod bacterium (Mycobakterium tuberculosis). This research is a descriptive nature experiment is to determine the presence of bacteria mycobacterium tuberculosis in sputum of patients cough $\geq 2$ weeks in the Internal Medicine Clinic Dr BLU. Prof. Dr. Kandou with smear using Ziehl Neelsen.The results are 50 samples, 23 (46\%) positive and 27 (54\%) negative.Presentation by gender with the most positive smear on male sex $65.2 \%$ from than $34.8 \%$ of women.Presentation of the age group with the highest incidence of smear positive cases in the age group 55-74 years old 39.3\%. Conclusion: Examination of acid fast bacilli in the sputum of patients cough $\geq 2$ weeks needs to be done in order to determine the existence of bacteria mycobacterium tuberculosis.Tuberculosis is most common in males than in females in the age group 55-74 years old.
\end{abstract}

Keyword: cough more than two weeks, tuberculosis, BTA.

\begin{abstract}
Abstrak: Batuk $\geq 2$ minggu merupakan gejala utama diagnosis penyakit tuberkulosis yang disertai dengan dahak. Gejala yang menyertai yaitu batuk yang mengeluarkan darah, nafsu makan menurun, penurunan berat badan, keringat pada malam hari (tanpa aktifitas) dan ada tanda-tanda infeksi.Tuberkulosis paru ini adalah penyakit yang menyerang paru yang disebabkan oleh bakteri batang gram positif (Mycobakterium tuberkulosis).Penelitian ini merupakan penelitian deskritif bersifat ekperimen yaitu untuk mengetahui adanya kuman mycobacterium tuberkulosis pada sputum penderita batuk $\geq 2$ minggu di Poliklinik Penyakit Dalam BLU RSUP.Prof. Dr. Kandou dengan di lakukan pemeriksaan BTA mengunakan pewarnaan ziehl neelsen.Hasil penelitian terdapat 50 sampel, 23 (46\%) positif dan 27 (54\%) negatif. Presentasi berdasarkan jenis kelamin dengan bta positif terbanyak pada jenis kelamin laki-laki 65,2\% daripada perempuan 34,8\%. Presentasi kelompok umur dengan bta positif terbanyak terjadi pada kelompok umur 55 - 74 tahun 39,3\%. Simpulan: Pemeriksaan basil tahan asam (BTA) pada sputum penderita batuk $\geq 2$ minggu perlu dilakukan agar mengetahui adanya kuman mycobacterium tuberkulosis. Tuberkulosis paling sering terjadi pada laki-laki dibandingkan perempuan pada kelompok umur 55 - 74 tahun.
\end{abstract}

Kata Kunci: batuk lebih dari 2 minggu, tuberkulosis, BTA. 
Batuk adalah refleks pertahanan yang timbul akibat iritasi trakeobronkial. Kemampuan untuk batuk merupakan mekanisme membersihkan saluran nafas bagian bawah. ${ }^{1}$ Batuk juga merupakan reaksi pertahanan tubuh yang dapat melindungi paru-paru. Gejala ini perlu diwaspadai, apabila berlangsung lebih dari dua minggu. ${ }^{2}$

Batuk $\geq 2$ minggu merupakan gejala utama dari penyakit Tuberkulosis Paru yang disertai dengan batuk dahak.Adapun gejala yang menyertai lainnya adalah penurunan berat badan. Tanda-tanda infeksi seperti (demam), keringat pada malam hari (tanpa melakukan aktifitas), dan nafsu makan menurun. ${ }^{3}$

Tuberkulosis Paru adalah penyakit menular akut maupun kronis yang terutama menyerang paru. Tuberkulosis paru disebabkan oleh bakteri batang gram positif (Mycobacterium tuberculosis). Mycobacterium tuberkulosis dapat menular dari individu yang satu ke individu lainnya melalui percikan droplet yang terbawa oleh udara, seperti batuk, dahak atau percikan ludah. $^{4}$

Tuberkulosis paru di Indonesia merupakan masalah besar dan merupakan penyebab kematian nomor tiga di dunia setelah Cina dan India.Berdasarkan dari data WHO tahun 1997, di dunia setiap tahunnya terdapat sembilan juta orang yang terkena TBC, dan lebih dari dua juta orang meninggal dunia. Diperkirakan setiap 100.000 penduduk Indonesia terdapat 130 penderita baru TB Paru BTA positif. Setiap satu penderita TBC yang positif akan menularkan 10-15 orang penduduk setiap tahunnya. $^{5}$

Data Riskesdas 2007 menunjukan sekitar 7,5 \% angka kematian Indonesia disebabkan oleh penyakit TB Paru. Dari data tersebut didapatkan prevalensi TB paru DI Provinsi Sulawesi Utara begitu meningkat sesuai bertambahnya umur dan prevalensi tertinggi pada usia lebih dari 65 tahun. Prevalensi TB paru 20\% lebih tinggi pada laki-laki dibandingkan perempuan, tiga kali lebih tinggi di pedesaan dibandingkan perkotaan dan empat kali lebih tinggi pada pendidikan rendah dibandingkan pendidikan tinggi. ${ }^{6}$

Pemeriksaan mikroskopis BTA dari sputum memegang peran dalam mendiagnosis awal dan pemantauan pengobatan Tuberkulosis paru. Rangkaian kegiatan yang baik diperlukan untuk mendapatkan hasil yang akurat, mulai dari cara pengumpulan sputum, pemilihan bahan sputum yang akan diperiksa dan pengolahan sediaan dibawah mikroskop. Teknik pewarnaan yang digunakan adalah Ziehl Neelsen yang dapat mendeteksi BTA dengan menggunakan mikroskop. ${ }^{7}$

Berdasarkan uraian ringkas di atas bahwa, belum pernah ada laporan tentang gambaran pemeriksaan BTA pada penderita batuk $\geq 2$ minggu, sehingga penulis tertarik untuk melakukan pemeriksaan batuk $\geq 2$ minggu.

\section{METODE PENELITIAN}

Penelitian ini merupakan penelitian deskritif bersifat ekperimen yaitu untuk menemukan kuman Mycobakterium Tuberculosis dari sputum penderita batuk $\geq 2$ minggu di poliklinik Penyakit Dalam BLU. Prof. Dr. R.D Kandou Manado dengan mengunakan pemeriksaan BTA yang dilakukan pada bulan November 2012 sampai Desember 2012 bertempat di Balai Penunjang Kesehatan Dinas Kesehatan Provinsi Sulawesi Utara.

\section{Alat dan bahan penelitian}

Alat: botol sputum, ose/sengkelit, kaca objek (slide), spidol permanen, rak sediaan, sarung tangan, masker, stop watch, lampu spritus, alkohol. Bahan: sputum, larutan carbol fuchsin 0,3\%, larutan asam alkohol (HCL alkohol 3\%), larutan methylen blue 0,3\%, xylol.

\section{Cara kerja}

1. Cara pengambilan sputum

a. Beri label yang jelas mengenai identitas pasien pada bagian dinding sebelah luar pot sputum. 
b. Sputum yang diambil harus berasal dari trakea atau bronkus, bukan saliva (air liur).

c. Pasien disuruh berkumur dengan air sebelum mengeluarkan sputum.

d. Tarik nafas dalam 2-3 kali setiap kali hembusan nafas dengan kuat.

e. Letakkan pot sputum yang sudah dibuka dekat dengan mulut dan keluarkan sputum kedalam pot.

f. Tutup rapat pot dengan cara memutar tutupnya.

2. Cara pembuatan sediaan

a. Pembuatan preparat

Ambil pot dahak dan kaca sediaan yg beridentitas sama dengan pot dahak. Kemudian buat sediaan hapus, sbb: Panaskan ose diatas nyala api spritus sampai merah dan biarkan dingin kemudian ambil dahak oleskan merata pada permukaan kaca sediaan dan dekatkan ose pada api spiritus sampai kering dan sediaan dibiarkan diudara yang terbuka. Setelah setengah kering, buat lingkaran kecil-kecil dgn mngunakan lidi lancip kemudian lewatkan sediaan diatas lampu spiritus sebanyak 3x untuk difiksasi dan letakkan sediaan pada rak pengecatan untuk diwarnaidengan pewarnaan ziehl neelsen.

b. Pewarnaan dengan metode Ziehl Neelsen.

Sediaan yang sudah difiksasi diletakan pada rak pewarnaan dengan hapusan sputum menghadap keatas kemudian teteskan larutan carbol fuchsin $0,3 \%$ pada hapusan dahak sampai menutupi seluruh permukaan sediaan selanjunya dipanaskan degan api spritus sampai keluar uap slma 3-5 menit. Kemudian bilas dengan air yang mengalir pelan sampai zat wrna terbuang lalu teteskan dengan asam alkohol (HCL alkohol 3\%) sampai warna merah fuchin menghilang. Selanjunya bilas degan air yang mengalir pelan lalu teteskan larutan methylen blue $0,3 \%$ pada sediaan sampai menutupi seluruh permukaan dan diamkan 10-20 detik lalu bilas dengan air mengalir pelan kemudian keringkan sediaan diatas rak pengering diudara yang terbuka.

\section{Hasil penelitian}

Penelitian yang dilakukan di Bagian Poliklinik Penyakit Dalam BLU RSUP. Prof. Dr. R. D Kandou Manado pada pengambilan sampel selama bulan November 2012 - Desember 2012.

Tabel 1. Distribusi Hasil Pemeriksaan BTA.

\begin{tabular}{lcl}
\hline Hasil Penelitian & Jumlah & $\mathbf{\%}$ \\
\hline Positif & 23 & 46 \\
Negatif & 27 & 54 \\
Total & 50 & 100 \\
\hline
\end{tabular}

Pada tabel 1 pemeriksaan BTA kasus batuk > 2 minggu ditemukan 23 (46\%) yang positif TB Paru dan 27 (54\%) negatif.

Tabel 2. Distribusi kasus berdasarkan jenis kelamin.

\begin{tabular}{lcl}
\hline Jenis Kelamin & Jumlah & \% \\
\hline Laki-laki & 15 & 65,2 \\
Perempuan & 8 & 34,8 \\
Total & 23 & 100 \\
\hline
\end{tabular}

Pada tabel 2 pemeriksaan BTA positif berdasarkan jenis kelamin paling banyak ditemukan pada laki-laki yaitu (65,2\%) daripada perempuan yaitu $(34,8 \%)$.

Tabel 3. Distribusi berdasarkan kelompok umur.

\begin{tabular}{lcc}
\hline Umur & Jumlah & \% \\
\hline $15-34$ & 5 & 21,7 \\
$35-54$ & 7 & 30,4 \\
$55-74$ & 939,3 & \\
$\geq 75$ & 28,6 & \\
Total & 23100 & \\
\hline
\end{tabular}


Pada tabel 4 pemeriksaan BTA positif ditemukan paling banyak terdapat (39,3\%) pada kelompok umur 55 - 74 dan paling sedikit terdapat (8,6\%) pada kelompok umur $\geq 75$ tahun.

\section{BAHASAN}

Penelitian ditemukan 50 sampel kasus batuk $\geq 2$ minggu yang datang berobat di Poliklinik Penyakit Dalam BLU RSUP. Prof. Dr. R.D Kandou Manado dan dilakukan pemeriksaan Basil Tahan Asam di Balai Penunjang Kesehatan Dinas Kesehatan Provinsi Sulawesi Utara pada bulan November 2012 - Desember 2012.

Distribusi hasil pemeriksaan BTA penderita dengan hasil positif Tb Paru pada penelitian ini terdapat 23 sampel sedangkan yang hasil negatif terdapat 27 sampel.Ini dikarenakan pada penelitian banyak sputum yang terdapat air liur (saliva) dibandingkan dahak. Hasil ini tidak sesuai dengan penelitian Hendra Wijaya di Fakultas Kedokteran Universitas Sam Ratulangi tahun 2011 yang menyatakan bahwa BTA positif jumlah terbanyak pada penderita suspek TBC ada 670 sampel dibandingkan BTA negatif hanya 220 sampel. $^{9}$

Distribusi kasus berdasarkan jenis kelamin pada penderita batuk $\geq 2$ minggu dengan hasil positif Tb Paru tertinggi pada penelitian ini adalah laki-laki dibandingkan perempuan. Hal ini sesuai dengan penelitian dr. Leli Saptawati dkk tahun 2012 menyatakan bahwa infeksi TB Paru memang cenderung lebih sering diderita laki-laki dibandingkan perempuan. Hal ini antara lain disebabkan karena faktor kebiasaan merokok yang dapat meningkatkan risiko infeksi TB paru sebanyak 2,2 kali. ${ }^{10}$

Kebiasaan merokok akan merusak mekanisme pertahanan paru yang disebut mucociliary clearance. Bulu-bulu getar dan bahan lain di paru tidak mudah membuang infeksi yang sudah masuk karena bulu getar dan alat lain di paru rusak akibat asap rokok. Selain itu, asap rokok meningkatkan tahanan jalan nafas (airway resistance) dan menyebabkan mudah bocornya pembuluh darah di paru-paru, juga akan merusak makrofag yang merupakan sel yang dapat memfagosit bakteri patogen. ${ }^{11}$

Merokok dapat menggangu efektifitas sebagian mekanisme pertahanan respirasi. Hasil dari asap rokok dapat merangsang pembentukan mucus dan menurunkan pergerakan silia. Dengan demikian terjadi penimbunan mukosa dan peningkatan risiko pertumbuhan bakteri termasuk kuman TB Paru sehingga dapat menimbulkan infeksi. ${ }^{12}$

Pada hasil penelitian yang diperoleh, menunjukkan bahwa penderita dengan positif $\mathrm{Tb}$ Paru pada laki-laki dan perempuan sering terjadi pada kelompok umur di atas 54 tahun. Hasil penelitian ini sesuai dengan data riskesdas 2007 didapatkan pada prevalensi TB Paru di Provinsi Sulawesi Utara cenderung meningkat sesuai bertambahnya umur dan prevalensi tertinggi pada usia lebih dari 65 tahun. ${ }^{6}$ Pada penelitian ini berbanding terbalik pada penelitiannya Rikha Nurul Pertiwi dkk alumnus Fakultas Kesehatan Masyarakat UNDIP tahun 2011 dari hasil analisis statistik menunjukkan bahwa umur responden tidak mempunyai hubungan bermakna dengan kejadian TB Paru dan umur 15-55 tahun mempunyai risiko terkena TB Paru dengan risiko 0,667 kali lebih besar dibandingkan umur $>55$ tahun. Hal tersebut dikarenakan ketahanan tubuh mulai menurun setelah umur 45 tahun sehingga rentan terkena penyakit. ${ }^{13}$

\section{SIMPULAN}

1. Jumlah penderita batuk $\geq 2$ minggu yang berobat di Poliklinik Penyakit Dalam selama bulan November 2012 Desember 2012 ditemukan sebanyak 50 kasus.

2. Jumlah kasus dari hasil pemeriksaan BTA adalah jenis basil tahan asam yang positif sebanyak 23 (46\%) dan jenis basil tahan asam negatif sebanyak 27 (54\%).

3. Jenis kelamin dengan BTA positif pada pasien batuk $\geq 2$ minggu paling banyak terjadi pada laki-laki dibandingkan perempuan. 
4. Umur terbanyak pada pemeriksaan BTA positif pada laki-laki dan perempuan terjadi pada umur di atas 54 tahun.

5. Kekurangan penelitian ini tidak dilakukan anamnesis mengenai faktor resiko.

6. Sampel penelitian ini kebanyakan air liur (saliva) meskipun sudah diberi edukasi tentang cara pengambilan sputum.

\section{SARAN}

1. Perlu diwaspadai batuk $\geq 2$ minggu dengan dilakukan pemeriksaan BTA.

2. Pada penelitian selanjutnya perlu ditanyakan faktor resiko pada penderita batuk $\geq 2$ minggu.

3. Pada penelitian selanjutnya perlu ditanyakan pengobatan sesuai dosis yang dipakai pada batuk $\geq 2$ minggu.

\section{DAFTAR PUSTAKA}

1. Price SA,Wilson LM. Tanda Dan Gejala Penting Pada Penyakit Pernafasan. Dalam: Hartanto H, Susi N, Wulansari P, Mahanani DA, editor. Patofisiologi Konsep Klinis Proses-Proses Penyakit Vol 2 (Edisi ke-6). Jakarta: Penerbit Buku Kedokteran EGC, 2006; p.773.

2. Waspadai batuk lebih dari 2 minggu [homepage on the Internet]. 2010 [cited 2012 Oct 20]. Available from: http://health.kompas.com/read/2010/01/19/ 11085499/Waspadai.Batuk.Lebih.dari.2.Mi nggu.

3. Batuk lama [homepage on the Internet]. 2011 [cited 2012 Oct 20]. Available from: http://kesehatan.kompasiana.com/medis/20 11/07/06/batuk-lama/.

4. Susanto AD. Analisis kadar interferon gamma pada penderita tuberkulosis paru dan orang sehat. Jurnal Respirologi Indonesia. 2010;30:119

5. Rusnoto, Rahmatullah $P$, Udiono A. Pemantauan efektisitas obat anti tuberkulosis berdasarkan pemeriksaan sputum pada penderita tuberkulosis paru. Jurnal Kesehatan. 2010;3:2.

6. Lumentut $\mathbf{N}$. Pencapaian pembangunan kesehatan. Dalam: Tim Dinas Kesehatan Propinsi Sulawesi Utara, editor. Profil Kesehatan Propinsi Sulawesi Utara. Sulut: Balai Penerbit Dinas Kesehatan Sulut, 2008; p.26,30.

7. Handayani TE. Pemeriksaan mikroskopis BTA pada sputum pasien diduga TB paru di Balai Kesehatan Paru Masyarakat Wilayah Semarang pada bulan Maret April 2011 [disertasi]. Semarang: Fakultas Kedokteran Universitas Muhammadiyah Semarang; 2011.

8. Wijaya H. Prevalensi basil tahan asam positif pada penderita suspek tuberkulosis paru di Poliklinik Paru Bagian Penyakit Dalam RSUP Prof. Dr. R.D Kandou Manado Periode Januari 2010 - Desember 2010 [disertasi]. Manado: Fakultas Kedokteran Universitas Sam Ratulangi Manado; 2011.

9. Saptawati L. Evaluasi metode fastplaqueTBTM untuk mendeteksi mycobacterium tuberculosis pada sputum beberapa unit pelayanan kesehatan di Jakarta-Indonesia. Jurnal Tuberkulosis Indonesia. 2012;8:4.

10. Zainul M. Hubungan kebiasaan merokok dengan konversi sputum penderita TB paru di Klinik Jemadi Medan [disertasi]. Medan: Fakultas Kedokteran Universitas sumatera Utara Medan; 2009.

11. Widyasari RN, Wuryanto MA, Setyawan H. Hubungan antara jenis kepribadian, riwayat diabetes mellitus dan riwayat paparan merokok dengan kejadian TB paru dewasa di Wilayah Kecamatan Semarang Utara Tahun 2011. Jurnal Kesehatan Masyarakat. 2012;1:447.

12. Pertiwi RN, Wuryanto MA, Sutiningsih D. Hubungan antara karakteristik individu, praktik hygiene dan sanitasi lingkungan dengan kejadian tuberkulosis di Kecamatan Semarang Utara Tahun 2011. Jurnal Kesehatan Masyarakat. 2012;1:437-38. 